\title{
The Effectiveness of Learning Instruments of Speaking Containing Character Values toward Speaking Learning
}

\author{
N. M. R. Wisudariani ${ }^{*}$, I N. Sudiana, I. B. Putrayasa, and I W. Rasna \\ Language Education Study Program, Universitas Pendidikan Ganesha Singaraja, Indonesia
}

\begin{abstract}
This development research aimed at describing the effectiveness of learning instruments of speaking that were contained in character values. The objects of the study were a syllabus, lesson plan, textbook, and assessment. The subjects of the study were the lecturers of Speaking and the $2^{\text {nd }}$-semester students of IIA, IIB, and IIC in the academic year of 2015/2016. The data was collected through observation, questionnaire, and test. The data was analyzed by administering descriptive qualitative technique and descriptive statistics. The results of the study showed that the learning instruments was effective to be used in the teaching and learning process, to improve students understanding on the materials, to improve students speaking skill, and to shape characters such as religious, polite, communicative, open, democratic, respectful, responsible, curious, discipline, confident, cooperative, appreciate achievement, logic, critic, creative and innovative, and love reading. The results of the study indicated that the learning instruments of speaking contained of character values were effective so that it was feasible to be used by both lecturers and students of Indonesian Language and Literature Department, Language and Art Faculty of Ganesha University of Education.
\end{abstract}

\section{Introduction}

The logical consequence of the implementation of a curriculum is right in a learning process. Teaching and learning process become the most important key to achieve learning objectives. To achieve this, learning instruments must be well-prepared in the learning interaction. Preparation of a good learning tool is a strategic step in the management of learning process to achieve the achievement of graduate learning optimally. Lecturer as an educator has a very big responsibility of preparing learning instruments that can optimize the ability of learners to have the readiness to face the demands and needs of the times. Learning instruments consist of at least syllabus, lesson plan, textbook, and assessment.

Learning instruments that are absolutely needed in the teaching and learning process. In teaching language skill courses, the availability of learning instruments is very helpful for lecturers and students. The lecturers do not need to present too many materials in the classroom so that they have more opportunities to guide the students. The students can use the learning instruments as a source of learning and it can lead the students to be independent learning. By using learning instruments, the students will be put up in

\footnotetext{
*Corresponding author: rai.wisudariani85@gmail.com
} 
readiness to join a course and it will enable the students to accelerate their learning $[1,2,3,4]$.

The learning instruments developed by the lecturers should be based on the prediction of future needs. The learning outcomes in multi-purpose speaking course indicate that the students do not have a conceptual understanding of the material. It has affected the students' skill in speaking. The students' behavior in speaking has not yet lead better. The symptom of this character decline is a reflection of the results of education in our country. The achievement educational outcomes seem to indicate that there is something missing which has not yet been actualized in our national education. Moral deterioration gives a strong indication that education in our country faces a dilemma. Some of these facts are proven that character education has not been implemented well at the higher education level.

It is undeniable that news in mass media all the times still highlights the graduates of higher education institutions which are considered "smart and having no character". Mohammad Nasir and Ganjar Pranomo in a separate place stated that higher education is not only responsible for the development of the ratio, but also the character of young generation. The task of higher education institutions do not only produce graduates to improve the quality of education in Indonesia, but they are also responsible for character building of their graduates. Character education in higher education is a stage of character building which is as important as the character building at the school level $[5,6,7]$. In response to this situation, the lecturer can integrate character values into their all subjects' matters through the development of a multi-purpose speaking learning instruments containing values of character education.

In order to produce good quality learning instruments, learning instruments must have one of the criteria of effectiveness. The effective learning instruments are simply defined that learning instruments are developed appropriately and achieved expected goals as to provide a meaningful experience for users $[8,9]$. Based on the existing problems, the focus of the study in this study concerns on the effectiveness of learning instruments Speaking is characterized by the value of the characters in the teaching and learning process, increasing the students' understanding of the learning materials, improving students' speaking skills, and the formation of student character.

The results of this study were expected to contribute to the enrichment of science and knowledge, especially for the fulfillment of literature in the field of interactional communication skills. For intuitions, the results of this study can be used as a model for developing the learning instruments which aligned with the graduate competencies, to foster education character in which the teaching and learning atmosphere can truly reflect self-actualization on the basis of the values of character of our nations, and to carry out the concepts of Tri Hita Karana, one of which is to maintain harmonious relations between human and human (pawongan) as contained in the vision of our institution. For lecturers, the learning developed instruments can be used in speaking course, so that the teaching and learning process become more effective. In addition, the results of this study can be used as a model for other lecturers to develop the learning instruments as mandated by law. For students, the product developed in this study was expected to facilitate the students in their learning and encourage the students' independence to understand the material, so that the students can master speaking competencies and they will have a good character when communicating orally.

\section{Method}


This study adapted model 4D and ADDIE. The model consists of five steps, namely define, design, develop, evaluate, and disseminate [10]. In the first step, the researchers conducted a preliminary analysis, ability and character analysis, concept analysis, tasks analysis, and learning objectives analysis, lesson planning analysis, material analysis, and character values analysis relevant to the material. In the second step, the results of the analysis were used to design and develop learning instruments. In the third step, the researchers developed the learning instruments which have been designed. Furthermore, the development included the validation of the learning instruments by a panel of experts and try-out of the learning instruments. Being examined the validity of the learning instruments, then they were tried out.

The try-out of the effectiveness of the learning instruments of Speaking that are contained in character values was conducted at Indonesian Language and Literature Department, Faculty of Language and Art, Ganesha University of Education. The participants were the students of the $2^{\text {nd }}$-semester students of IIA, IIB, and IIC in academic year 2015/2016. There were totally 54 students involved in this study. In this case, 14 students of class IIA participated in small group try-out, and 19 students of class IIB and 21 students of class IIA participated in field tryout. The instruments used to collect the data in this study were observation sheet, questionnaire, and an interview guide. This study applied two techniques of data analysis, namely the qualitative descriptive and descriptive statistical analysis techniques.

\section{Results and Discussion}

The results of this study showed that the learning instruments of Speaking have the value of effective characters used in the teaching-learning process, improving students' understanding of learning materials, improving students' speaking skills, and forming the values of the characters in the students themselves. The average understanding of small group students (2C) on learning materials amounted to 79 was good. The average understanding of students of large groups (2B) on learning materials amounted to 81 was good. The average understanding of students of large groups (2A) on learning materials of 76 was also quite good. It indicated that effective learning tools are used in improving students' understanding of learning materials

Based on the result of practice test of speaking to the students of a small group (2C) it was known that the average of students' speaking skill was 84, it was good. The results of midterms and final semester exam showed an excellent achievement improvement. The average score of students' speaking skills in the midterm exam was 87 and the average score of students' speaking skills in the final exam at the end of the semester was 91 . The middle and final semester test results were very good. Based on the result of practice test of speaking to the students of a big group (2B) it was known that the average of students' speaking skill was 83 , it was good. The results of midterms and final exam results showed an excellent improvement. The average score of students' speaking skills in midterm and final examination of the semester is 85 . The middle and final exam results were very good. Based on the result of practice test of speaking to the students of a big group (2A) it was known that the mean value of the practice of students' speaking skill is 78 , it is good. The middle and final exam results show a good improvement. The average score of students' speaking skills in the midterm exam and the final exam of the semester of 80 was quite good. The results of this test of speaking skills showed that effective learning tools are used in improving students' speaking skills.

In implementing the value of character education, this learning tool is also effective to use. The value of religious, polite, communicative, open, democratic, respectful, responsibility, curiosity, discipline, self-confidence, cooperation, rewarding achievement, 
creative and innovative critical logic character, as well as the value of a reading habit which is focused on learning Speaking has begun to develop to students. This suggests that the Speaking learning instruments has consisted with an effective character value used in implanting the student's character values.

Based on the results, there were several findings in this study. Firstly, the use of learning instruments that were structured in the lecture is the application of Behavioristic learning theory. The Behavioristic sees the importance of conditioning environment. The conditioning of the learning environment affects the learning process and outcomes itself. In Connectionism learning theory, the conditioning of learning by using instructional learning instruments as a stimulus is closely related to the three theorems found by Thordike, the law of readiness, the law of exercise and the law of effect. With the existence of learning tools, both students and lecturers become more ready in the teaching-learning process, because lecturers and students understand the direction of the lecture. The more ready the lecturers and students do the teaching-learning process, then the implementation of learning will lead to satisfaction or good results.

The learning of speaking is done through the practice of speaking. The more students are trained to practice speaking, the students' skills in speaking will get better as well. The principle of exercise law states that the ability of students will be more increased and strengthened if being trained repeatedly. In the process of teaching and learning, the lecturer also reflects on the students' performance. The results of this reflection provide a pleasant impact or vice versa for students. When the results of reflection received by students are fun, students tend to improve their speaking skills. If the results of reflection received by students are not very pleasant, the student's tendency will improve the appearance.

Secondly, the use of the learning instruments was able to place the lecturers as a facilitator in the lecture and the students as a subject who owned an independence in the lecture. At the time the lecturer of the course is unable to be present in the classroom, the students can learn independently by answering the questions in the competency test as well as in reflection section. In this case, the learning instruments is an important part of lecture [11]. Through a textbook, the lectures will be easier to teach and the students will be easier to learn. Teaching and learning through learning instruments can be defined as a significantly meaningful strategy for the success of a teaching and learning process. The meaningfulness of the learning instruments can be seen from the ability of the learning instruments especially textbook developed to bring about self-instruction for the students. It means that the developed textbook has the ability to explain clearly how the teaching materials should be learned by the students in the teaching and learning process, both with the help of a lecturer or students independently. These findings more and more strengthen the position of a textbook in the field of education.

Thirdly, the elaboration of the material in the learning instruments containing the values of character education was able to build and instill the character values in the students themselves. The development of this learning instruments containing character values is aimed to increase the students' understanding of the theoretical basis for speaking of various interaction and its applications, and the establishment of character values in the students themselves. The learning instruments do not simply provide an understanding, but it instills values in the students themselves. The three things concern the knowledge of the students of the values, the students' moral feeling, and the students' behavior pertaining to the values. The students' knowledge of the elaboration of the material containing the values of character education has a positive effect on the skill of the students in their learning. It means that the effect of using the learning instruments containing character is not only restricted to knowledge but it also has something to do with skills and attitudes. 
The elaboration of the material in the learning instruments serves as a tool to build a competency, character, and a foundation for the appreciation and implementation of the character values. This matter has a connection with the feelings of the students (moral feeling) after using the learning instruments. This study also showed that the understanding and improvement of the students' skills after using the textbook end in the attitudes reflected by the students in the lecture. The characterized behavior come up, develop and strengthen in the students themselves because they know the concepts and natures of characterized behavior, feel and possess a positive attitude towards the concept of a good character, and they are accustomed to practicing it [12-23]. The results of observation and test indicated that the students who can understand the material will be skillful in speaking and they will automatically display mutual respect, appreciate their friend who performs in front of the class.

\section{Conclusion}

The results of try-out showed that the learning instruments developed can bring about a positive impact on the multi-purpose speaking course and the continuity of character education in this country. In relation to this, there are three important things to be stated here, namely recommendation for the utilization of the product, dissemination of the product, and further development of the product. For the utilization of the product, the learning instruments were developed to meet the needs of the students and lecturers in speaking course at the Department of Indonesian Langauge and Literature Education, Ganesha University of Education. Concerning its relevance to the lecture, these learning instruments need to be reviewed when it is going to be used by the lecturers and the students outside our department. However, this textbook can be used as one of the sources by other institutions in teaching speaking skill. In cases of the utilization and dissemination of the product, the results of this study are limited to own sides. If the product will be used for the interest of the wider community, it needs to be revised by considering the scope of the subject which is not restricted only to the need of the lecturers and the students of language education. For further development of the product, the product developed in this study is simply learning instruments, therefore other researchers are expected to develop suitable media to support the learning instruments.

\section{References}

1. Suhadi, Petunjuk perangkat pembelajaran (Surakarta, Unmuh, 2007)

2. Hobri, Metode penelitian pengembangan:aplikasi pada penelitian pendidikan matematika (Jember: Universitas Jember, 2009)

3. Chodijah, S., J. Plt. Pbl Fis 20, 1-19 (2012)

4. B.G. Davis, Tools for teaching: perangkat pembelajaran, teknik mempersiapkan dan melaksanakan perkuliahan yang efektif (Jakarta: Raja Grafindo Persada, 2013)

5. L. Nucci, University of illinois at chicago follows nationwide movement toward character education (ascribe column, Dec 14, 2004).

6. N. Chanifah, Desain pendidikan karakter di perguruan tinggi umum (Prosiding Seminar Nasional Senari III, 47-51, 2015)

7. Sandra, Graham, D. Marry E., J. Research in Character E 11, 34 (2015)

8. B. Seel, Richey, R. C., Teknologi Pembelajaran: Definisi dan Kawasannya (Washington D.C: Association for Educational Communication and Technology,1994).

9. J.V.D. Akker, Design Approaches and Tools in Education and Training (Dortrech: KluwerAcademic Publishers, 1999). 
10. S.S. Thiagarajan, Semmel, M.L. Instructional development for training teacher of exceptional children (Minnesota: Indiana University,1974).

11. Lestari, Pengembangan bahan ajar berbasis kompetensi: sesuai dengan kurikulum tingkat satuan pendidikan (Jakarta: Akademia, 2013).

12. M. Elias, J R. Character E 2, 246-266 (2007)

13. M.B. Adeyemi, T.V. Moumakwa, D. Adeyemi, J In. Stud Home Comm, Sci 3, 118-128 (2009)

14. T. Lintner, Soc. Stud. J 102, 200-213 (2011)

15. T. Lickona, Educating For character: mendidik untuk membentuk karakter, bagaimana sekolah dapat mengajarkan sikap hormat dan tanggung jawab (Jakarta: Bumi Aksara, 2012)

16. Tyra, J Ris Tide 5, 1-10 (2012)

17. N. Silay, Eur J of E Stud 5, 131-138 (2013)

18. M. Yaumi, Syahid, Character education values that work in islamic senior high school (Seminar Nasional, YPUP Makasar,2013)

19. B.M. Protz, Character education in print: content analysis of character education in introduction to education textbooks (Dissertation, University of North Carolina, 2013).

20. A.M. Gina, $R$ High $E J$ 26, 2 (2014)

21. S.A. Khan, J Edu R Inter 3, 97-106 (2014)

22. B. Tonia, S. Peter, J Character Edu 10, 155-174 (2014)

23. D.S.S. Mihardi, J Edu Pract 6,162-171 (2015) 